\title{
АНАЛИЗ СИСТЕМЫ КОНТРОЛЯ ПРОТИВОДЕЙСТВИЯ ИСПОЛЬЗОВАНИЯ ДОПИНГА СПОРТСМЕНАМИ В РОССИЙСКОЙ ФЕДЕРАЦИИ
}

\author{
А. А. Волков, О. Ю. Минченкова \\ Московский гуманитарный университет
}

Аннотация: В статье рассмотрены особенности организации современной системы контроля противодействия использования допинга спортсменами России. Рассматриваются ключевые элементы организации системы, факторы, влияющие на эффективность антидопингового контроля.

Ключевые слова: антидопинговый контроль; система контроля допинга; российский спорт; допинг; спортсмен

\section{ANALYSIS OF THE CONTROL SYSTEM OF INTERDICTION OF DOPING ABUSE BY ATHLETES IN THE RUSSIAN FEDERATION}

\author{
A. A. Volkov, O. Yu. Minchenkova \\ Moscow University for the Humanities
}

Abstract: The article analyses the organization of a modern control system of interdiction of doping abuse by Russian athletes. The key elements of the organization of the system, as well as factors affecting the efficiency of anti-doping control are considered.

Keywords: anti-doping control; doping control system; Russian sport; doping; athlete

\section{Введение}

По итогам ряда правовых и социальных преобразований в России создана достаточно целостная система противодействия допингу в спорте, определены полномочия и особенности деятельности различных участников этого процесса, объемы финансирования и порядок осуществления антидопинговых мероприятий.

В системе противодействия допингу в спортивной среде вопросы разработки антидопинговой политики отнесены к ведению Министерства спорта, туризма и молодежной политики, одно из подразделений которого координирует работу по антидопинговой деятельности (Абсалямов, 2014: 54).

Известно, что в системе противодействия допингу в России ключевыми субъектами деятельности являются некоммерческое партнерство «РУСАДА» (реализует главные мероприятия допинг-контроля) и ФГУП «АДЦ» - лаборатория, аккредитованная ВАДА, которая осуществляет исследова- 
Научные труды Московского гуманитарного университета

2019 № 1

ния проб спортсменов на содержание допинговых веществ. Регламент взаимодействия этих субъектов определен приказом № 307 Минспорттуризма от 13 апреля 2011 г., который утвердил Общероссийские антидопинговые правила, которые отражают приоритеты национальной политики в сфере противодействия допингу, особенности проведения допинг-контроля, включая порядок осуществления запросов, дисциплинарные процедуры (Антидопинговые законопроекты, 2015: 54). Именно взаимодействию будет уделено внимание в статье.

22 ноября 2011 г. в России принят Федеральный закон «0 внесении изменений в Кодекс Российской Федерации об административных правонарушениях и статьи 26 и 261 Федерального закона «0 физической культуре и спорте в Российской Федерации», который позволил штрафовать тренеров и врачей за нарушение антидопингового законодательства и международных норм.

Достаточно важную роль в системе противодействия допингу играет партнерство с организацией «РУСАДА». Некоммерческое партнерство «Российское антидопинговое агентство» создано в 2008 г. Ключевые направления его деятельности состоят в разработке и внедрении национальных антидопинговых норм, проведение тестов на допинг, проведение научных исследований по борьбе с допингом, расследование нарушений норм допингового законодательства, международное сотрудничество. «РУСАДА» сегодня выступает одной из ведущих организаций по числу тестирований (ежегодно агентство проводит 20 тыс. допинг-проб) (Антидопинговый кодекс, 2016: 21).

В 2009 г. «РУСАДА» подписано трехстороннее соглашение с ВАДА и Антидопинговым агентством Норвегии, с целью подготовки «РУСАДА» к сертификации по ISO 9001, в 2011 г.«РУСАДА» было сертифицировано по ISO 9001(Горюнов, 2014: 8).

Сегодня система противодействия допингу в России постепенно совершенствуется с привнесением опыта других государств. В частности, Федеральным законом от 07.05.2010 № 82-ФЗ «0 внесении изменений в Федеральный закон «0 физической культуре и спорте в Российской Федерации» внесен ряд норм, которые детализируют и регулируют отдельные аспекты борьбы с допингом, ранее не регулируемые нормативными актами, направленные на создание комплекса мер противодействия допингу (Абсалямов, 2014: 50). Ранее ст. 26 Федерального закона № 329-Ф3 не давала трактовки термина «допинг», а лишь устанавливала запрет по противодействию применения различных допинговых средств, в то время как само понятие «допинг» несколько более широкое (Антидопинговое законодательство, 2015: 7).

Законодатель сегодня определяет допинг в спортивной деятельности как нарушение антидопингового правила, в т.ч. использование (попытка использования) метода или веществ, включенных в перечни, запрещенных для применения в спорте. Перечень запрещенных к применению допинго- 
вых методов и средств составляется по стандарту ВАДА и обновляется ежегодно (Антидопинговое законодательство, 2015: 7).

На современном этапе допинговый контроль в общем виде направлен на противодействие нарушению антидопинговых правил - как российских, так и международных (Антидопинговый кодекс, 2016: 70).

Таким образом, систему организации работы по противодействию допингу можно представить следующим образом (см. рис.).

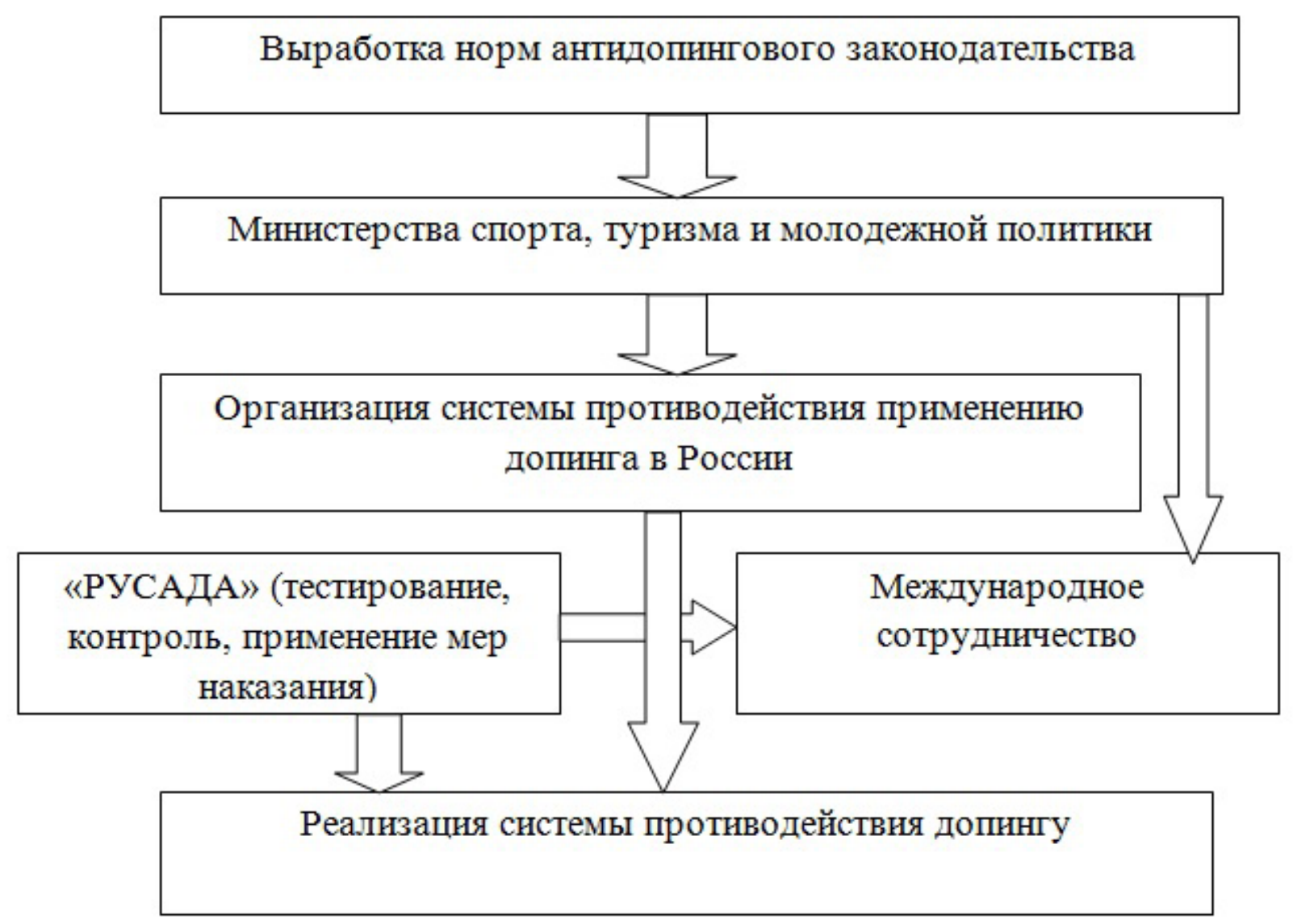

Рис. Система контроля и противодействия допингу.

В общем виде система работы работа системы противодействию допингу включает в себя несколько этапов:

Первый этап - тестирование - это первая часть допинг-контроля, которая включает общее планирование тестирования, отбор проб, их транспортировку в лабораторию и анализ. Тестирование осуществляется с целью получения доказательства соблюдения спортсменом запрета на применение запрещенных субстанций или методов. Проверка наличия субстанций проводится через лабораторные анализы.

Правила реализации тестирования регулируются Всемирным антидопинговым кодексом и Международным стандартом по тестированию и 
Научные труды Московского гуманитарного университета

2019 № 1

расследованиям. Российская система допинг-контроля принимает во внимание требования этих документов.

В соответствии с требованиями, результаты анализа проб должны быть предоставлены в антидопинговую организацию в срок до 10 рабочих дней после предоставления пробы в лабораторию. Срок предоставления результатов анализа может быть изменен по предварительной договоренности.

Второй этап - анализ отобранных проб. В соответствии с требованиями Всемирного антидопингового кодекса пробы спортсменов на содержание допинга могут быть подвергнуты анализу только в лабораториях, аккредитованных ВАДА. В настоящий момент в мире аккредитовано 34 таких лаборатории.

При проведении лабораторных анализов лаборатория не располагает информацией о личности спортсмена, его имя, фамилия и данные должны быть зашифрованы. В лабораторию передаются лишь данные о номере пробы, которые позволяют затем, «привязать» результаты анализа к личности и биологическому профилю каждого конкретного спортсмена в системе АДАМС. Деятельность лабораторий урегулирована Международным стандартом по лабораториям.

Третий этап - расследование, который имеет место в случае обнаружения проб, в которых явно либо условно зафиксированы вещества, отнесенные к запрещенным международным законодательством. Согласно уставу «РУСАДА» к одному из ключевых видов деятельности относится именно расследование случаев нарушения антидопингового законодательства (Международная конвенция ... , 2017).

Команда отдела по расследованиям «РУСАДА» на этапе расследования применяет опыт расследований различного рода неаналитических нарушений. Деятельность отдела регламентирована законодательством Российской Федерации, антидопинговыми правилами, Международным Стандартом по тестированию и расследованиям.

Отдел по расследованиям «РУСАДА» занимается сбором и анализом медицинской информации, её проверкой, а также, при необходимости, оперативным реагированием в безотлагательных случаях. Также в функционал отдела по расследованиям «РУСАДА» входит работа с осведомителями, при сохранении их конфиденциальности и поощрении стремление оказывать содействие в противодействии употреблению допинга.

Четвертый этап предполагает обработку результатов в случае, если возникает подозрение либо обнаружение нарушений антидопингового законодательства. При получении информации в результате тестирования и анализа проб о неблагоприятном результате анализа либо ином нарушении антидопинговых правил инициируется процедура обработки результатов, главной целью которой выступает установление факта нарушения (либо его отсутствия) и, при необходимости, определение меры наказания по нормам Всемирного антидопингового кодекса. 
При получении в результате анализа неблагоприятного результата осуществляется первоначальное рассмотрение проб и материалов анализа для определения того, имеются ли явные отступления от Международного стандарта по тестированию и расследованиям или Стандарта для лабораторий, которые могли привести к неблагоприятному результату анализа. Также выявляется, есть ли разрешение на терапевтическое использование обнаруженного в пробе препарата.

При отсутствии разрешения на терапевтическое использование выявленного в пробе вещества или выявлении отклонения от правил тестирования, которые могли бы стать причиной неблагоприятного результата, РУСАДА уведомляет спортсмена, спортивную и международную федерации и ВАДА о результате анализа (Горюнов, 2014: 65).

Спортсмен при возникновении спорного либо неблагоприятного результата имеет право:

1. Немедленно запросить дополнительное либо повторное проведение анализа (если подобный запрос от спортсмена не поступит в установленные сроки, это будет трактовано как отказ от анализа),

2. Присутствовать при анализе и вскрытии своей повторной пробы либо направить на данную процедуру своего представителя,

3. Подать запрос на предоставление копий пакетов документов по анализу проб, содержащих информацию по Международному стандарту для лабораторий.

В случае неблагоприятного результата исследования проб на спортсмена будет наложено временное отстранение. Отстранение является обязательным при обнаружении в пробе субстанции, которая не относитсяк особой, либо выявлено использование спортсменом запрещенного метода. В иных случаях решение о временном отстранении остается на усмотрение РУСАДА. Спортсмен при этом имеет право подать дополнительно запрос на проведение более оперативных по срокам слушаний по вопросу временного отстранения, как меры наказания. У спортсмена есть также и право добровольно со своей стороны согласиться с его временным отстранением.

В заключение следует отметить, что допинговый скандал выявил отношение к России со стороны международного спортивного сообщества, как к стране, имеющей «дикие» убеждения, заведомо нарушающей установленные правила. Отчасти, это объясняется традиционным неприятием России в период существования СССР, когда идеология Советского Союза противостояла идеологии большинства капиталистических стран. Безусловно, такое отношение к нашей страны со стороны западных стран достаточно негативно сказывается не только на потенциальных дипломатических отношениях, но и на самоощущении и гражданской идентичности российского народа, как социальной общности «второго сорта».

В то же время, явная несправедливость к российским спортсменам со стороны международного сообщества, во многом является тем фактором, 
который способствует объединению и сплочению народа России против несправедливости. Кроме того, это показывает чрезмерную политизированность международного спорта, его явную зависимость от политических отношений, что несколько дискредитирует международное спортивное сообщество не только в глазах российских спортсменов, которые обижены явной несправедливостью, но и в глазах всего мира.

Немаловажным является и специфика трактовки ситуации с употреблением допинга, когда ошибка и нечестность нескольких конкретных спортсменов (которые были бы наказаны и со стороны России, и по всей вероятности, в любом случае не допущены на Игры) негативно сказывается на всей российской олимпийской команде. Данный принцип «круговой поруки», конечно, несправедлив по отношению к спортсменам, не употребляющим допинг, но пострадавших в допинговом скандале, но в то же время, такая ситуация станет толчком к тому, чтобы формировать у российских спортсменов более высокий уровень социальной ответственности. В частности, складывается понимание того, что любая ошибка или мошенничество, отразится негативно не только на конкретном спортсмене, но и на все команде России, и в конечном счете - на имидже страны (Антидопинговый кодекс, 2016: 54).

Такая социальная ответственность для спортсменов достаточно важна, поскольку они являются в отдельных случаях «лицом» российского народа на международной арене, а также примером для подрастающего поколения.

Таким образом, допинговый скандал оказал, как отрицательное, так и положительное влияние на российское спортивное сообщество, и российский народ в целом. В частности, он поспособствовал росту социальной ответственности спортсменов и послужил фактором сплочения российского народа. Кроме того, допинговый скандал явно продемонстрировал излишнюю политизированность, и, следовательно, предвзятость международного спортивного сообщества (и МОК в первую очередь) для всего мира.

В то же время возникший допинговый скандал обусловил необходимость совершенствования системы антидопингового законодательства и организации работы в области противодействия применению допинга в спорте.

\section{СПИСОК ЛИТЕРАТУРЫ}

Абсалямов, Т. М. (2014) Борьба с допингом в Российской Федерации // Вестник спортивной науки. № 1 (3). С. 45-49.

Антидопинговый кодекс (2016) // Спорт в школе. № 9 (1-15 мая).

Антидопинговые законопроекты (2015) // Спорт : экономика, право, управление. № 3. С. 46-48.

Горюнов, В. Д. (2014) Об усилении ответственности спортсменов и специалистов сборных команд России за применение или содействие при- 
менению запрещенных субстанций и методов // Сборник официальных документов и материалов. № 6. С. 31-32.

Машковцев, А. (2017) Спорт без допинга // Спорт в школе. № 1.

Международная конвенция о борьбе с допингом в спорте / ООН по вопросам образования, науки и культуры (2017) // Спорт : экономика, право, управление. № 1. С. 31-45.

Дата поступления: 20.12.2018 2.

Волков Артем Андреевич - студент магистратуры кафедры менеджмента Московского гуманитарного университета. Адрес: 111395, Россия, г. Москва, ул. Юности, д. 5. Тел.: +7 (499) 374-70-13. Эл. адрес: volkovtema17@ yandex.ru

Минченкова Ольга Юрьевна - доктор экономических наук, профессор кафедры менеджмента Московского гуманитарного университета. Адрес: 111395, Россия, г. Москва, ул. Юности, д. 5, корп. 2. Тел.: +7 (499) 374-70-13. Эл. адрес: kafedra612@mail.ru

Volkov Artem Andreyevich, Graduate Student, Moscow University for the Humanities. Postal address: 5, Yunosti St., Moscow, Russian Federation, 111395. Tel.: +7 (499) 374-70-13. E-mail: volkovtema17@yandex.ru

Minchenkova Olga Yuryevna, Doctor of Economics, Professor, Department of management, Moscow University for the Humanities. Postal address: 5, Yunosti St., Moscow, Russian Federation, 111395. Tel.: +7 (499) 374-70-13. E-mail: kafedra612@mail.ru

\section{Для цитирования:}

Волков А. А., Минченкова О. Ю. Анализ системы контроля противодействия использования допинга спортсменами в Российской Федерации [Электронный ресурс] // Научные труды Московского гуманитарного университета. 2019. № 1. URL: http://journals.mosgu. ru/trudy/article/view/946 (дата обращения: дд.мм.гг.). DOI: 10.17805/trudy.2019.1.17 